\title{
A Review: Protease Inhibitors From Sponge Jaspis Sp. Associated Bacteria
}

\author{
Dede Mahdiyah ${ }^{1 *}$, Bayu Hari Mukti \\ \{mahdiyahdede@yahoo.co.id ${ }^{1}$, muktibh001@gmail.com $\left.{ }^{2}\right\}$ \\ ${ }^{1}$ Department of Pharmacy, Faculty of Health, Universitas Sari Mulia, Banjarmasin, Indonesia. \\ ${ }^{2}$ Department of Educational Biology, STKIP PGRI Banjarmasin, Indonesia. \\ *Corresponding author: mahdiyahdede@yahoo.co.id
}

\begin{abstract}
Protease inhibitors are enzymes that function to inactivate target proteases secreted by pathogenic bacteria to humans such as emphysema, pancreatic disease, arthritis, thrombosis, high blood pressure, cancer, and AIDS. The sponge is a good natural source for producing bioactive components including enzyme inhibitors. Jaspis sp is a genus from a sponge that has potential compounds as a protease inhibitor to combat Pseudomonas aeruginosa, Staphylococcus aureus, and EPEC K11. The interaction of sponges with bacteria occurs in the form of commensalism symbiosis that produces bioactive compounds that are important for human life.
\end{abstract}

Keywords: marine bacteria, Jaspis sp., protease inhibitors

\section{Introduction}

Sponges referred to as "chemical factories" because many bioactive compounds are found therein [1]. The bioactive compounds are derived from the association of sponges with bacteria that live in them [2]. Sponges are simple multicellular invertebrates attached to benthic habitats of solid substrates. Sponges are filter feeder organisms that have pores on the surface of the body so that water can enter and circulate through channels or channels where microorganisms and other organic particles can be filtered and eaten [3].

The sponge is a source of natural product sources in the form of bioactive compounds, namely enzyme inhibitors, cell division inhibitors, antiviral, antifungal, antimicrobial, anti-inflammatory, antitumor, and cytotoxic [4]. One example of a sponge that produces bioactive compounds is Achantella sp., As a producer of kalibinol-A that functions as an antibiotic, Jaspis jhonstoni is known to be able to produce cytotoxic jasplakinolide compounds [2]. In addition, Jaspis sp. which produces protease enzymes [5], has the ability antimicrobial compound [6] and has the ability to produce protease inhibitors [7], [8].

Microorganisms perform symbiosis with a sponge with the aim of being a protective place from predators and also as a food source. The results of the symbiosis of microorganisms with a sponge are compounds that are beneficial to health. Groups of microorganisms that are symbiotic with sponges are from archaea, heterotrophic bacteria, cyanobacteria, green algae, red algae, and diatoms [6].

Protease inhibitor compounds from Jaspis sp. the result of bacterial symbiosis with a sponge has benefits for antibiotics that can inhibit bacterial pathogens in humans. In this article, we will review protease inhibitor compounds obtained from bacteria associated with Jaspis sp. based on our research results.

\section{Jaspis sp.}


Jaspis $\mathrm{Sp}$ is a genus of sponges. Sponges from the Jaspis genus are reported to contain many biologically active molecules, including macrolides [9], cyclic peptides [10], and amino acid derivatives [11]. Association of two sponges Jaspis sp. and Poecillastra sp. known to contain bisimidazole.

Coarse $\mathrm{MeOH}$ extracts from the association of two Jaspis sp. and Poecillastra sp. were subjected to fractionation guided activity using solvent partitioning and reverse-phase flash column chromatography followed by repeated phase reverse HPLC to produce compounds 1-5, namely new lysophosphatidylglycerol (1 and 2) together with lysophosphatidylgliserol (3) and glycolipid (4 and 5). The structure of these metabolites was concluded using NMR (1H, 13C, COZY, HSQC, and HMBC) and MS analysis, optical rotation data, and by direct comparison with those reported [12].

Natural sources of bioactive from Jaspis sp have functioned as antibacterial to $S$. aureus, Escherichia coli, and Salmonella typhi and antifungal towards Candida albicans [13]. Ethyl acetate extract (JDE) of the Mauritian sponge Jaspis sp. can lead accumulation of cells in the G2/M phase after $24 \mathrm{~h}$ by added JDE $100 \mathrm{ng} / \mathrm{ml}$, causing a significant increase of cells in sub-G1 phase suggesting that JDE can induce cell cycle arrest in G2/M phase [14].

\section{Protease Inhibitor}

Enzyme inhibitors have been isolated from various organisms both in terrestrial and in the ocean. Enzyme inhibitors are considered as compounds that are especially useful for the potential of biotechnology in pharmacology [15] and agriculture. In particular, enzyme inhibitors, namely protease inhibitors, are important examples of enzyme inhibitors capable of deactivating target proteases in human diseases (such as high blood pressure, arthritis, muscular dystrophy, pancreatitis, thrombosis, different cancers, and AIDS [16]).

Protease inhibitors are compounds that can block the active site of protease to prevent the substrate from binding to the active site of the enzyme [17]. The protease inhibitor works by preventing viral replication by preventing HIV-1 protease activity, which is an enzyme used by viruses to split proteins become a collection of virions [18].

Protease inhibitors can be proteins, peptides, or small molecules. Protease inhibitors that occur naturally are usually proteins or peptides. Protease inhibitors used in experimental research or drug development often take the form of small molecules or synthetic peptides. Many various protease inhibitors are commercially available for experimental use both in in vitro and in vivo testing and during protein purification.

Protease inhibitors are produced by marine microorganisms associated with sponges. The search for protease inhibitors from marine bacteria begins with the process:

a. Bacterial isolation from Jaspis sp. The sponge is rinsed with sterile synthetic seawater so that contaminant bacteria that are not associated with the sponge are not isolated so that only bacteria with a strong combining force will be isolated. Bacterial isolation on the surface of the sponge is done by wiping the surface of the sponge at three different places using a $1 \mathrm{~cm}$ sterile swab, then dipping it into 3 pieces Erlenmeyer containing sterile PBS media. From each of these tubes, a series of dilutions are carried out from $10^{-1}-10^{-5}$. The last three dilutions were spread in SWC (seawater complete) media and incubated at room temperature for 24 hours. Growing colonies were purified by the quadrant method and preserved in sloping agar [7].

b. Screening of protease inhibitor-producing bacteria associated with sponge Jaspis sp 
Screening is done using the plate method for two-layer skim milk [19]. The lower layer consists of SWC media, and the upper lip consists of agar nutrient (NA) which is given a skim of $1.5 \%$. The marine bacterial isolates to be filtered were inserted into the lower layer then incubated 24 hours and 48 hours at $30^{\circ} \mathrm{C}$. The growing isolates were discarded, then given the top layer. The test bacteria in this study were pathogenic bacteria namely $P$. aeruginosa, $S$. aureus, and EPEC K11. Inserted at the top then incubated for 24 hours at $37^{\circ} \mathrm{C}$. Isolates that produce protease inhibitors are indicated by the absence or reduction of the protease zone around the pathogenic bacterial colony [7].

The percentage of protease inhibition was calculated using the formula:

$$
\text { Percentage of inhibition }=\left(1-\frac{\text { Percentage treatment zone }}{\text { control protease zone }}\right) \times 100 \%
$$

The percentage of inhibition was categorized into three categories: strong (> 80\%), moderate $(>60 \%)$, and weak $(<50 \%)$.

Bacteria that have the potential to produce protease inhibitors are what cause pathogenic bacteria to be unable to degrade skim proteins. This is indicated by the formation of protease zones or decreasing the diameter of protease zones around pathogenic bacteria.

Some types of protease inhibitors are a serine protease, cysteine protease, and metalloprotease. These three types of proteases are widespread in many pathogenic bacteria, which play a critical function related to colonization and avoidance of the host immune defense, acquisition of nutrients for growth and proliferation, facilitation of spread, or tissue damage during infection [20].

\section{Mechanisms of Protease Inhibitor}

Protease inhibitors can work in various ways to inhibit the action of proteases. These inhibitors can be classified based on the type of proteases they inhibit and the mechanisms that inhibit these enzymes. Reversible inhibitors usually bind to the protease with multiple noncovalent interactions, without any change to the inhibitor itself. Reversible inhibitors include competitive inhibitors, uncompetitive inhibitors, and non-competitive inhibitors.

A competitive inhibitor binds to the active site of the protease, competing with substrates for access to the active site residues [21]. Uncompetitive inhibitors bind to the protease only when it is already attached to a substrate [22]. Non-competitive inhibitors bind to the protease with similar affinities, regardless of the presence of a bound substrate [23].

Several of protease inhibitors are competitive and bind to the active protease site, but also have a secondary binding site outside the active site, which is very important for inhibition. Exotic bonds provide two main benefits; it increases the surface area of proteinprotein interactions, which leads to greater affinity, and can have a significant effect on the specificity of the inhibitor.

Escherichia coli serine protease inhibitor ecotin uses its exocytes to provide binding energy and actually expand the free association of inhibitors and protect bacteria from host proteases. Ecotin is a dimeric protein that inhibits folding protease serine protease regardless of their primary specificity. It functions as a dimer, and inhibits protease serase through standard mechanisms at the primary binding site, but also has a secondary binding site that can contribute up to $5 \mathrm{kcal} / \mathrm{mol}$ of binding energy to a very strict enzyme inhibiting complex. Surprisingly, the individual binding energy of the two binding sites is not additive; the effect of the secondary binding site on affinity was found to be inversely proportional to the binding 
strength at the primary site. The secondary binding site seems to provide a compensating effect that can overcome sub-optimal binding at the primary binding site; if the bond at the primary site is not optimal, secondary bond interactions tend to be stronger. In this way, the exocytes actually make inhibitors less specific, or better able to inhibit various proteases and allow one bacterial inhibitor to protect against a number of host proteases [24].

\section{Bacteria that produce protease inhibitors}

Bacteria that were successfully isolated from the surface of the sponge Jaspis sp have the ability to produce protease inhibitor compounds, from the screening test results with a two-layer method to be compared against pathogenic protease-producing bacteria in humans. After undergoing bacterial DNA isolation testing and analysis of DNA base sequences with DNA sequencers and their kinship analysis with phylogenetic trees obtained three potential bacteria producing protease inhibitors, namely Paracoccus sp., Jx9 with $86 \%$ similarity identity, Bacillus pumilus strain $210-50$ with $100 \%$ similarity identity and Bacillus subtilis strain DURCK11 with $98 \%$ similarity identity [7].

One of the first marine bacterial isolates that were successfully isolated as a source of producing enzyme inhibitors is Alteromonas sp., from which the serine inhibitors and cysteine proteases have been isolated [25]. Examples of serine protease inhibitors are represented by marinostatins C-1 and C-2, which are used as drugs [26]. Bacteria associated with Providencia $s p$. showed inhibitory activity against protease subtilisin. Pyrostatins A and B are protease inhibitors of strains of Streptomyces SA-3501 isolated from the sea, have inhibitory activity against $\mathrm{N}$-acetyl-b-D-glucosaminidase (GluNAc-ase) which is used as a drug for diabetes [27], leukemia [28], and cancer [29].

\section{Optimum conditions for the production of protease inhibitors Activity}

Production Protease inhibitor activity is influenced by $\mathrm{pH}$, temperature, substrate, and incubation time. It is proven that the isolate of bacteria associated with sponge Jaspis $\mathrm{sp}$. has an optimum $\mathrm{pH}$ under acidic $\mathrm{pH}$ conditions $(\mathrm{pH} 4)$, and other types of bacteria have an optimum $\mathrm{pH}$ of 7 and 8 . While the optimum temperature for the production of protease inhibitors is obtained at $30^{\circ} \mathrm{C}$. Based on the conditions of the substrate used is the average of protease inhibitors against subtilisin is very low compared to the proteinase $\mathrm{K}$ substrate, whereas in crude extracts the inhibitory activity of protease inhibitors produced is very high. In proteinase $\mathrm{K}$ substrate bacteria from sponge Jaspis sp have protease inhibitor activity both after an incubation time of 12 hours and 20 hours, on the rough extract substrate at 24 hours incubation time. Subtilisin substrate obtained high protease inhibitor activity at 20 hours [7].

\section{Conclusion}

Bacteria associated with Jaspis sp Sponge can produce protease inhibitor compounds that function to block the active sites of protease enzymes produced by human pathogenic bacteria are $P$. aeruginosa, $S$. aureus, and EPEC K11 as a form of pathogenicity of these bacteria in infecting humans, and the activity of protease inhibitors influenced by $\mathrm{pH}$, substrate, temperature, and incubation time.

\section{Acknowledgements}

The authors would like to thanks the Ministry of Religion of the Republic of Indonesia, for funding my research in 2007.

\section{Conflict of intersest}


No conflict of interest.

\section{References}

[[1] N. Ruocco, S. Costantini, F. Palumbo, and M. Costantini, "Marine Sponges and Bacteria as Challenging Sources of Enzyme Inhibitors for Pharmacological Applications," Mar. Drugs, vol. 15, no. 173, pp. 1-16, 2017, doi: $10.3390 / \mathrm{md} 15060173$.

[2] Y. Lee, J. Lee, and H. Lee, "Microbial Symbiosis in Marine Sponges Microbial Symbiosis in Marine Sponges," J. Microbiol., vol. 39, no. 4, pp. 254-264, 2001.

[3] C. R. Wilkinson, "Microbial Associations in Sponges . II . Numerical Analysis of Sponge and Water Bacterial Populations," Mar. Biol., vol. 49, pp. 169-176, 1978.

[4] M. Munro et al., "The discovery and development of marine compounds with pharmaceutical potential," Biotech, vol. 70, pp. 15-25, 1999.

[5] D. Mahdiyah, "Isolasi Bakteri Dari Tanah Gambut Penghasil Enzim Protease," J. Pharmascience, vol. 2, no. 2, pp. 71-79, 2015.

[6] O. K. Radjasa, D. S. Kencana, A. Sabdono, R. A. Hutagalung, E. S. Lestari, and M. Studies, "Antibacterial Activity of Marine Bacteria Associated with sponge Aaptos sp . against Multi Drugs Resistant ( MDR ) strains," pp. 1-6, 2007.

[7] D. Mahdiyah, "PENAPISAN DAN IDENTIFIKASI BAKTERI YANG INHIBITOR PROTEASE," Institut Pertanian Bogor, 2010.

[8] A. Wahyudi, Qatrunnada, and N. Mubarik, "Screening and Characterization of Protease Inhibitors from Marine Bacteria Associated with Sponge Ja," Hayati J., vol. 17, no. 4, pp. 173-178, 2010.

[9] J. Kobayashi, O. Murata, H. Shigemori, and T. Sasaki, "Jaspisamides A-C, new cytotoxic macrolides from the Okinawan sponge Jaspis sp," J nat Prod., vol. 56, pp. 787-791, 1993.

[10] F. Gala et al., "New jaspamide derivatives with an- timicrofilament activity from the sponge Jaspis splendans.," Tetrahedron, vol. 63, pp. 5212-5219, 2007.

[11] Z. Thale et al., "Bengamides revisited: New structures and antitumor studies," J Org Chem, vol. 66, pp. 1733-1744, 2001.

[12] P. Shinde, T. Park, D. Kim, J. Hong, and J. Jung, "New Glycerides from a TwoSponge Association of Jaspis sp . and Poecillastra sp .," Pharm. Biol., vol. 46, no. 1011, pp. 814-818, 2009, doi: 10.1080/13880200802315717.

[13] F. Astuti, S. Utami, T. Hertiani, G. Alam, and A. Tahir, "Marine Sponge Jaspis sp , A Potential Bioactive Natural Source against Infectious diseases," Berk. Kedokt., pp. 17, 2002.

[14] G. Beedessee et al., "Ethyl acetate extract of the Mauritian sponge Jaspis sp . induces cell arrest in human promyelocytic leukemia cells," Environ. Toxicol. Pharmacol., vol. 36, no. 1, pp. 58-65, 2013, doi: 10.1016/j.etap.2013.03.002.

[15] W. Bode and R. Huber, "Natural protein proteinase inhibitors and their interaction with proteinases," Eur. J. Biochem., vol. 204, pp. 433-451, 1992.

[16] H. Demuth, "Recent Developments in Inhibiting Cysteine and Serine Proteases," $J$. Enzym Inhib., vol. 3, no. July, pp. 249-278, 2015, doi: 10.3109/14756369009030375.

[17] A. Barret, N. Rawling, and J. Woessner, The handbook of proteolytic enzyme, 2nd Ed. Academic press, 2003.

[18] H. Bisswanger, Enzyme Kinetics Principles and Methods. Weinheim: Wiley, 2002.

[19] C. Imada, U. Simidu, and N. Taga, "Isolation and characterization of marine bacteria 
producing alkaline protease inhibitor,” Bull. Japanese Soc. Sci. Fish., vol. 51, no. 5, pp. 799-803, 1985.

[20] C. Supuran, A. Scozzafava, and B. Clare, "Bacterial Protease Inhibitors," Med. Res. Rev., vol. 22, no. 4, pp. 329-372, 2002, doi: 10.1002/med.10007.

[21] J. Chabbat, P. Porte, M. Tellier, and M. Steinbuch, "Aprotinin is a competitive inhibitor of the factor VIIa-Tissue factor complex," Thromb. Res., vol. 71, no. 3, pp. 205-215, 1993.

[22] T. Sperka, J. Pitlik, P. Bagossi, and J. Tozser, "Beta-lactam compounds as apparently uncompetitive inhibitors of HIV-1 protease," Bioorganic Med. Chem., vol. 15, pp. 3086-3090, 2005, doi: 10.1016/j.bmcl.2005.04.020.

[23] P. Johnston et al., "HTS identifies novel and spesific uncompetitive inhibitors of the two-component NS2B-NS3 proteinase of west nile virus," ASSAY Drug Dev. Technol, vol. 5, no. 6, pp. 737-750, 2007, doi: 10.1089/adt.2007.101.

[24] C. Faraday and C. Craik, "Mechanisms Of Macromolecular Protease Inhibitors," NIH Public Access, vol. 11, no. 17, pp. 2341-2346, 2014, doi: 10.1002/cbic.201000442.Mechanisms.

[25] C. Imada, N. Taga, and M. Maeda, "Cultivation conditions for subtilisin inhibitorproducing bacterium and general properties of the inhibitor 'marinostatin,", Bull Jap Soc Sci Fish, vol. 51, pp. 805-810, 1985.

[26] C. Imada, S. Hara, M. Maeda, and U. Simidu, "Amino acid sequences of marinostatins C-1 and C-2 from marine Alteromonas sp," Bull Jap Soc Sci Fish, vol. 52, pp. 14551459, 1986.

[27] J. Alhadeff and R. Holzinger, "Characterization of P-Hexosaminidase from Liver and Sera of Diabetic Patients and Controls," Biochem. Med., vol. 27, pp. 214-225, 1982.

[28] H. Drexler and G. Gaedicke, "ISOENZYME STUDIES IN H U M A N LEUKEMIA - III . p - H E X O S A M I N I D A S E ( E . C . 3 . 2 . 1 . 30 )," Leukimia Res., vol. 7, no. 5, pp. 611-619, 1983.

[29] J. Freitas, F. Rodrigue, P. Lavaud, Mencia-Huerta, and P. JM Braquet, "Inhibition of platelet aggregation by manoalide: preliminary results," Braz J Med Biol Res, vol. 21, pp. 337-340, 1998. 